\title{
NILAI-NILAI RELIGIUSITAS DALAM NOVEL BIDADARI PADERI KARYA SAIFUL A. IMAM
}

\author{
Nurmaya \\ Mariana Lewier \\ Falantino Eryk Latupapua \\ Universitas Pattimura \\ e-mail: nurmaya246@gmail.com
}

\begin{abstract}
Abstrak: Penelitian ini merupakan penelitian kualitatif dengan menggunakan kajian sastra religius. Metode analisis deskriptif digunakan untuk mendeskripsikan nilai-nilai religiusitas dalam novel Bidadari Paderi karya Saiful A. Imam. Analisis data berfokus pada dua aspek, yaitu aspek nilai religiusitas tauhid (keimanan) dan aspek nilai religiusitas akhlak (sikap perilaku). Aspek nilai religiusitas tauhid (keimanan) terdiri dari: 1) iman, 2) takwa, dan 3) tobat, sedangkan aspek nilai religiusitas akhlak (sikap perilaku) terdiri dari: 1) sabar, 2) rendah hati, 3) tawakal, 4) jujur, 5) ikhlas, dan 6) disiplin. Hasil penelitian ini menunjukkan bahwa novel Bidadari Paderi lebih banyak mengandung nilai religiusitas akhlak dibandingkan nilai religiusitas tauhid yang mengusung makna perjuangan. Perjuangan kaum paderi untuk melawan Belanda serta melakukan pembaharuan ajaran Islam di Minangkabau yang saat itu masih teguh memegang adat-istiadat walaupun telah memeluk Agama Islam. Pengarang bermaksud menunjukkan bahwa sebagai makhluk yang memiliki agama tidak cukup hanya dengan keyakinan terhadap Tuhan saja. Namun, keyakinan tersebut harus dibuktikan dengan akhlak yang mencerminkan keimanan kepada Sang Pencipta.
\end{abstract}

Kata Kunci:Sastra Religius, Novel, Nilai-Nilai Religiusitas 


\title{
VALUES OF RELIGIOSITY IN THE NOVEL BIDADARI PAD ERI BY SAIFUL A. IMAM
}

\author{
Nurmaya \\ Mariana Lewier \\ Falantino Eryk Latupapua \\ Universitas Pattimura \\ e-mail: nurmaya246@gmail.com
}

\begin{abstract}
This research is a qualitative study using religious literary studies. Descriptive analysis method is used to describe the values of religiousity in the novel Bidadari Paderi by Saiful A. Imam. Analysis of data in the focuses on two aspect, namely aspects of monotheistic religiosity (faith) and aspects of moral religiosity (attitude of behavior). Aspects of the value of monotheism (faith) consist of; 1) faith, 2) devotion, 3) penance. While aspects of the value of moral religiosity (attitude of behavior) consist of; 1) patience, 2) humility, 3) trust, 4) honesty, 5) sincerity, 6) discipline.The results of this study indicate that the novel Bidadari Paderi contains more values of moral religiosity than the value of monotheistic religiosity which compiles the meaning of struggle. The struggle of the paderi to fight the Dutch and to renew Islamic teaching in Minangkabau which at that time was still firm in holding customs despite having embraced Islam. The author intends to show that being a religious being is not enough just to believe in God. But, these beliefs must also be proven by morals that reflect the faith in the creator.
\end{abstract}

Keywords:Religious literature, Novel, Religious Values. 


\section{A. PENDAhULUAN}

Sastra merupakan suatu ilmu yang dapat dinikmati dan dimanfaatkan

oleh masyarakat, terutama sebagai media penyaluran pikiran atau imajinasi tentang kehidupan, tentang pengalaman hidup dan masalah-masalah kehidupan yang dialami oleh suatu kaum yang mencangkup hubungan antarmasyarakat, antarmanusia, manusia dengan Tuhannya, dan antar peristiwa yang terjadi dalam kehidupan seseorang yang dituangkan dalam sebuah karya sastra. Setiap karya sastra yang tercipta entah itu bisa berupa puisi, drama, atau pun novel berangkat dari kejadian yang dialami oleh pengarang atau orang lain yang memuat nilai-nilai yang dapat menjadi pembelajaran bagi pembaca.

Nilai-nilai yang terkandung dalam sebuah novel, bisa kita temukan pada tuturan para tokoh atau pun dari tindakan yang dilakukan oleh para tokoh dalam novel tersebut.Selain itu novel mempunyai berbagai genre, salah satunya yaitu novel bergenre religius.Nilai yang ditampilkan dalam sebuah novel religius adalah nilai-nilai yang berkaitan dengan kepercayaan yang dianut oleh setiap manusia.Mengulas mengenai nilai religius dalam sebuah novel, tidak terlepas dari peran agama dalam kehidupan manusia.

Menurut Jauhari (2010: 27), nilai religius merupakan perilaku seseorang yang sesuai dengan ajaran agama, penghayatan yang terus-menerus dilakukan oleh manusia, norma yang diyakini melalui perasaan batin yang ada hubungannya dengan Tuhan, perasaan takut, dan mengakui kebesaran Tuhan, tunduk, taat, dan penyerahan diri kepada Yang Maha Kuasa. Nilai religius dianggap sebagai simbol kepercayaan seseorang terhadap Tuhannya.

Merujuk dari teori Jauhari, maka aspek nilai religiusitas yang digunakan dalam penelitian ini terdiri dari dua aspek, yakni aspek nilai religiusitas keimanan (tauhid) dan aspek nilai religiusitas sikap perilaku (akhlak). Penelitian ini menggunakan kajian sastra religius yang memfokuskan pada nilai-nilai religiusitas dalam novel Bidadari Paderi karya Saiful A. Imam.

Saiful A. Imam merupakan seorang penulis yang bisa dikatakan kurang terkenal atau kurang memproduksi karya sastra. Namun, novel yang ditulis oleh Saiful A. Imam juga, pernah mendapatkan Penghargaan Novel Terbaik Nasional dalam Festival Novel 2009 dengan nominasi novel menggugah.

Novel yang telah ditulis oleh Saiful A. Imam, sudah diterbitkan sebanyak tiga buah novel di antaranya, yaitu novel Bidadari Paderi (2007) penerbit Republika, Janji Para Lelaki (2010) penerbit Semesta, dan Meniti Janji Bidadari Moga Kita Berjumpa di Surganya (2014) penerbit Diva Press. Alasan pemilihan novel Bidadari Paderi, karena novel ini lebih banyak mengandung nilai religius dibandingkan dengan dua novel lainnya. Novel Janji Para Lelaki lebih banyak mengandung nilai moral, dan novelMeniti Janji Bidadari Moga Kita Berjumpa di Surganya yangmerupakan lanjutan cerita dari novel Bidadari Paderi, lebih banyak mengandung nilai moral dan budaya. Selain itu novel Bidadari paderi mengisahkan sebuah kisah percintaan yang dibalut 
dengan nuansa keagamaan yang kuat, namun tidak membuang adat-istiadat yang telah berlaku di dataran Minangkabau. Hal inilah yang menjadi salah satu alasan penulis untuk mengajukan penelitian dengan judul nilai-nilai religiusitas dalam novel Bidadari Paderi karya Saiful A. Imam dengan tujuan yang ingin dicapai yaitu untuk menganalisis nilai-nilai religiusitas dalam novel Bidadari Paderi karya Saiful A. Imam.

\section{B. METODE PENELITIAN}

Penelitian ini merupakan penelitian kualitatif. Penelitian kualitatif adalah penelitian yang bermaksud untuk memahami fenomena tentang apa yang dialami oleh subyek penelitian, misalnya perilaku, persepsi, motivasi, tindakan, dan lain-lain (Moleong, 2017: 6). Metode yang digunakan adalah metode analisis deskriptif. Alasan peneliti menggunakan metode analisis deskriptif karena dapat menggambarkan dan memaparkan secara jelas nilai-nilai religiusitas dalam novel Bidadari Paderi karya Saiful A. Imam. Metode deskriptif yang digunakan oleh peneliti diharapkan dapat mencapai tujuan yang telah dirumuskan oleh peneliti secara baik dan jelas.

Data dalam penelitian ini berupa kata-kata, kalimat-kalimat, dan uraian paragraf yang mengandung atau merujuk pada nilai-nilai religiusitas dalam novel Bidadari Paderi karya Saiful A. Imam. Teknik pengumpulan data yang digunakan yaitu teknik pustaka, catat, dan baca. Data penelitian dianalisis berdasarkan dua aspek yakni, aspek nilai keimanan (tauhid) dan aspek nilai sikap perilaku (akhlak). Alasan digunakan dua aspek tersebut, karena disesuaikan dengan fokus penelitian yang ingin diteliti yaitu nilai religiusitas yang tidak hanya melihat pada keyakinan seseorang kepada Tuhan yang Maha Esa, namun peneliti juga ingin melihat dari segi sikap yang dapat mencerminkan keimanan mereka kepada Tuhan Yang Maha Esa.Data yang disajikan kemudian diketik dengan ukuran Font 11, spasi tunggal dan tabulasi $1.27 \mathrm{~cm}$ sebagai pembeda uraian atau penjelasan hasil analisis. Kemudian kutipan teks diikuti dengan judul novel, yaitu Bidadari Paderi (BP) dan nomor halaman.

\section{PEMBAHASAN}

Pada bagian ini, peneliti akan memaparkan data penelitian dan hasil analisis mengenai nilai-nilai religiusitas dalam novel Bidadari Paderi karya Saiful A. Imam. Nilai-nilai religiusitas yang dimaksud yaitu, nilai keimanan (tauhid) yang dibagi menjadi tiga subbab dan nilai sikap perilaku (akhlak) yang dibagi menjadi enam subbab.Berikut ini merupakan hasil analisis terhadap data penelitian.

1. Nilai Keimanan (Tauhid)

a. Iman

Menurut Kamus Besar Bahasa Indonesia „iman“ dapat diartikan sebagai keyakinan dan kepercayaan kepada Allah, nabi, kitab dan sebagainya (ed.3. Pusat Bahasa. 2005). Bagi kebanyakan orang iman kepada Allah terealisasi melalui keyakinan terhadap aturan-aturan yang dibuat dan ditaati oleh seluruh umat sebagai wujud kepercayaannya terhadap Allah dan mengagungkan segala keesaan yang dimiliki oleh-Nya.Iman 
ditunjukkan oleh pengarang melalui salah satu tokoh dalam novel Bidadari Paderiyang dapat dilihat pada kutipan berikut ini.

Sekuat apapun dia, sehebat apapun dia, dia pasti akan kalah. Karena kekuatan ituhanya milik Allah semata.Kebatilan sudah kehilangan sumber kekuatannya karena berada di jalan yang sesat.(BP, 47).

Konteks pada kutipandi atas menjelaskan bahwa, Imam Mudo yang merupakan seorang kader paderi sedang meyakinkan anak-anak muda yang melakukan latihan bela diri untuk berperang melawan Belanda.Sebagai wujud iman kepada Allah, Imam Mudo yakin bahwa tidak ada kekuatan yang lebih kuat yang dapat melebihi kekuatan Allah selama mereka berada di jalan yang benar.Keyakinan inilah yang digambarkan pengarang untuk menjelaskan bahwa sebagai manusia kita harus percaya kepada Allah karena sehebat apapun seseorang semua itu merupakan kehendak-Nya.Kita sebagai manusia hanya bisa percaya dan yakin kepada-Nya.Karena sesungguhnya Allah tidak menyukai orang-orang yang batil.Keyakinan yang ditunjukkan Imam Mudo kepada para pemuda, karena sebagai makhluk yang beriman dan percaya sudah sewajarnya jika mempercayai keesan dan kuasa Sang Pencipta.Manusia boleh berencana tetapi Allah yang menentukan segala nasib seseorang.Segala yang terjadi merupakan ujian yang harus dilewati setiap manusia sebagai cobaan terhadap keimanannya kepada Allah.

\section{b. Takwa}

Takwa dapat diartikan sebagai kesalehan hidup.Salah satu indikasi seseorang dikatakan beriman dan bertakwa kepada Sang Pencipta saat seseorang taat menjalankan perintah-Nya dan menjauhi larangan-Nya. Hal itu dijelaskan dalam Al-Qur ${ }^{\text {rean Surah }}$ (Al-Baqarah: 83). Bahkan Allah menjanjikan tempat terbaik bagi orang-orang yang bertakwa.Takwa kepada Allah dalam novel Bidadari Paderi digambarkan pengarang sangat jelas yang terdapat pada kutipan berikut ini.

Setelah berwudhu, laki-laki itu shalat Ashar di atas papan datar yang sengaja diletakkan di sana sebagai sajadah. (BP, 2).

Salah satu bentuk ketakwaan seseorang kepada Allah, yaitu dengan mengerjakan shalat.Konteks yang dibicarakan pada kutipandi atas, yaitu tentang seorang laki-laki bernama Jauhar yang meninggalkan semua pekerjaannya untuk melaksanakan salah satu perintah Allah.Karena telah memasuki waktu shalat Ashar, dia pun segera berwudhu dan melaksanakan shalat walau hanya beralaskan dengan sebuah papan yang dijadikan sebagai sajadah. Walaupun hanya beralaskan papan, lelaki itu tetap menjalankan Shalat sebagai wujud ketakwaannya kepada Sang Pencipta karena shalat merupakan perintah untuk setiap umat yang beragama muslim. Sikap ketakwaan Jauhar, karena ia sadar bahwa sholat merupakan tiang utama dalam agama dan termasuk juga dalam rukun iman pertama. Penjelasan tersebut sesuai dengan surah Al-Ankabut ayat 45, artinya 
"Dan dirikanlah shalat.Sesungguhnya shalat itu mencegah dari(perbuatan-perbuatan) keji dan mungkar. Dan sesungguhnya mengingat Allah (Shalat) adalah lebih besar (keutamaannya dari ibadah-ibadah yang lain). Dan Allah mengetahui apa yang kamu kerjakan".Ayat tersebut menjelaskan bahwa melaksanakan shalat merupakan hal yang paling utama karena dapat menjauhi kita dari segala dosa yang berasal dari bisikkan setan.

Jika dikaitkan dengan kutipandi atas, ayat tersebut juga menjelaskan bahwa mengutamakan shalat itu lebih penting dibandingkan dengan mengerjakan hal yang lain. Sehingga ketika waktu Ashar telah tiba Jauhar segera menjalankan perintah Allah sebagai bentuk ketakwaannya.Sebab itu, seseorang tidak boleh menunda-nunda shalat karena itu kewajiban yang harus dipatuhi sebagai insan yang bertakwa.Penggambaran sikap takwa Jauhar juga diperlihatkan pengarang secara jelas, sehingga pembaca dengan mudah menafsirkan sikap religiusitasnya.Hal itu pula didukung oleh penggunaan alur maju oleh pengarang.

\section{c. Tobat}

Menurut Kamus Besar Bahasa Indonesia „tobat" adalah sadar dan menyesal akan dosa (perbuatan yang salah atau jahat) dan berniat akan memperbaiki tingkah laku dan perbuatan (ed.3. Pusat Bahasa. 2005). Bentuk tobat yang digambarkan oleh pengarang pada tokoh yang ada dalam novel Bidadari Paderi dapa terlihat pada kutipan di bawah ini.

(1) Saya kemudian menyesal setelah punya anak.Saya tidak tahu agama, dan tak bisa mendidik anak-anak saya.Karena itu, saya hormat pada orang-orang seperti gerakan Paderi itu.Termasuk orang surau seperti angku Jauhar."(BP, 110).

Rasa penyesalan yang ditunjukkan oleh tokoh Sutan Ameh begitu jelas digambarkan oleh pengarang.Sutan Ameh merupakan seorang pedagang yang menyesali kehidupannya di masa lalu, karena dulu mengabaikan perintah Allah. Setelah iamenikah dan mempunyai anak, ia tidak bisa mengajarkan anak-anaknya ilmu agama sehingga mereka tumbuh menjadi anak-anak yang sangat tidak hormat kepada kedua orang tua. Ketika melihat orang-orang paderi dan orang surau yang sangat pandai dalam ilmu agama, membuat tokoh Sutan Ameh sangat menghormati mereka sebagai wujud memperbaiki kesalahannya di masa lalu. Sutan Ameh semakin menyesal saat anak sulungnya yang bernama Manjo tumbuh sebagai anak yang begitu keras kepala dan susah diatur. Hal tersebut dapat dilihat pada kutipanberikut.

(2)“Itulah, Jauhar. Mamak sudah salah mendidik anak.Menyesal rasanya sekarang, karena dulu malas ke surau. Kita tau anak perlu dididik, tetapi dengan apa. Pengetahuan tidak ada. Kita susah mencari hidup seperti ini, tetapi anak malah tumbuh seperti itu. Kerap sekali dia pulang pagi.Belum bisa membantu tua. "(BP,

116). 
Kutipan (2) hampir sama dengan kutipan (1) yang sama-sama menggambarkan tentang rasa penyesalan yang dialami tokoh Sutan Ameh terhadap dirinya di masa lalu yang begitu malas menjalankan perintah Allah. Ditambah pula dengan adanya plot konflik batin yang ditampilkan oleh pengarang membuat cerita menjadi lebih jelas. Pembaca tidak akan bertanya-tanya mengenai penyebabpenyesal yang dirasakan oleh Sutan Ameh.

Kutipan tersebut juga memberikan pesan, bahwa anak adalah cerminan dari orang tua.Baik tidaknya perilaku seorang anak tergantung dari didikan orang tuanya.Sehingga sangat penting jika orang tua juga harus pandai dalam urusan agama, bukan hanya pandai dalam urusan duniawi.Melihat Manjo tumbuh menjadi anak yang durhaka, membuat Sutan Ameh menyesal karena dulu tidak dapat mendidik mereka dengan ilmu agama yang baik, karena tidak memiliki pengetahuan yang cukup untuk mengajari mereka.Penyesalan yang dirasakan oleh Sutan Ameh merupakan perasaan wajar, karena beliau adalah seorang ayah dan kepala rumah tangga yang seharusnya mampu mendidik istri dan anak-anaknya di jalan yang benar.Tetapi malah sebaliknya, Manjo yang sudah tumbuh dewasa begitu menyusahkan orang tuanya.

2. Nilai Sikap Perilaku (Akhlak)

a. Sabar

Sikap sabar harus dimiliki oleh setiap manusia. Orang yang sabar akan memiliki ketenangan jiwa dan emosi dalam menghadapi masalah yang datang. Sikap Sabar dalam menghadapi segala cobaan ditunjukkan pengarang melalui salah satu tokoh dalam novel Bidadari Paderiyang terlihat pada kutipan berikut.

\section{Mohon doakan kami kuat dan sabar menerima cobaan ini."Mereka melangkah menapaki jalan kampung di bawah sinar matahari yang hampir tegak berdiri.(BP, 235).}

Kutipan di atas menggambarkan sikap Jauhar yang sangat sabar menerima cobaan yang Allah berikan kepadanya. Nenek yang merupakan orang yang paling Jauhar sayangi harus pergi meninggalkan dia menghadap Sang Ilahi. Melalui dialog di atas, Jauhar meminta doa kepada orang-orang terdekatnya agar ia tetap diberikan kesabaran melalui segala cobaan sambil berjalan di bawah teriknya matahari seusai pulang dari pemakaman. Walaupun dirasanya sakit, ia tetap kuat dan tabah untuk menjalani hidup karena Allah tidak akan membebani seseorang melainkan sesuai dengan kesanggupannya.

Hal tersebut merupakan hal yang lumrah dilakukan oleh setiap manusia saat kehilangan orang yang dicintai.Meminta doa agar diberi kesabaran untuk menghadapi segala cobaan yang menyakitkan. Sikap tersebut ditunjukkan Jauhar karena sebagai orang surau yang memiliki pengetahuan agama yang baik, mereka percaya bahwa 
seseorang yang telah pergi mengahadap Sang Pencipta merupakan jalan yang terbaik, karena mereka yakin Allah lebih mengetahui apa yang terbaik bagi setiap hambanya.

\section{b. Rendah Hati}

Orang yang memiliki sikap rendah hati senantiasa akan berperilaku baik kepada sesamanya dan disenangi oleh orang lain.Kerendahan hati seseorang dapat terlihat saat orang tersebut dipuji dan disanjung namun tidak memperlihatkan ekspresi yang berlebihan.Sikap rendah hati pada novel Bidadari Paderidapat terlihat pada kutipan berikut.

\section{"Dulu saya sering kena lecut, sekarang saya pula yang memegangnya.Kenapa tak diberikan pada Angkuh Kahar atau Angkuh Salim saja?"Jauhar setengah menolak sambil mencoba menguasai diri dan menghilangkan rasa berdebarnya.(BP, 18).}

Konteks dalam kutipandi atas, yaitu saat Jauhar setengah menolak saat diberi kepercayaan oleh Imam Mudo untuk memegang lecut yang disampaikan oleh Nilam.Sikap Jauhar yang menolak amanah tersebut menggambarkan Jauhar yang tetap rendah hati walaupun menjadi orang kepercayaan Imam Mudo.Padahal dalam kenyataannya, jika seseorang diberi sebuah kepercayaan mereka langsung mengambilnya. Penolakan tersebut juga karena Jauhar merasa bahwa ia tidak pantas memegangnya karena dulu sering terkena lecut dan memberi saran untuk diberikan saja kepada Salim atau Kahar.

Kutipan di atas juga menjelaskan sifat malu pada diri Jauhar. Sikap menolak yang dilakukan Jauhar menunjukkan bahwa ia adalah seorang pemuda yang sangat baik dan rendah hati. Hal ini sesuai dengan latar sosial budaya Jauhar dalam cerita sebagai seorang guru mengaji yang dilukiskan oleh pengarang.Untuk lebih memperjelas watak Jauhar dalam novel Bidadari Paderi,pengarang memunculkan ekspresi berdebar.Penggambaran ekspresi tersebut oleh pengarang dengan melukiskan suasana hati yang gugup agar pembaca dapat merasakan suasana yang ingin diungkapkan oleh pengarang.

\section{c. Tawakal}

Tawakal berarti penyerahan diri dan menerima dengan sepenuh hati atas segala keadaan yang Allah berikan kepadanya. Bersikap tawakal bukan berarti seseorang lantas memasrahkan segala urusannya dan cobaan yang ia hadapi kepada Allah, tetapi juga harus disertai dengan usaha yang dapat ia lakukan sesuai dengan batas kemampuannya. Sikap tawakal ini juga tampak pada dialog-dialog yang terdapat dalam novel Bidadari Paderi yang terlihat pada kutipan dibawah ini.

"Sabarlah kawan, semua ini sudah ketentuan Allah.Kita perlu berlapang

dada menerimanya," Jauhar membujuk hati Salim.(BP, 103). 
Kutipandi atas, menggambarkan sikap menerima keadaan dan menyerahkan sepenuhnya masalah yang dihadapi kepada Allah.Latar suasana sedih yang ditampilkan pengarang menambah warna religiusitas dalam cerita. Jauhar yang dibuang dari kampung tetap merasa bersyukur atas apa yang diberikan kepadanya. Berbeda dengan Salim yang tidak menerima putusan untuk hukuman dibuangnya Jauhar dari kampung dan ingin membalas dendam kepada anak-anak yang telah menfitnah sahabatnya itu.Namun, dengan ikhlas dan sabar Jauhar menenangkan sahabatnya yang sedang marah.

Walapun dalam keadaan yang terhimpit, Jauhar tetap merasa bahwa semua itu adalahjalan terbaik yang Allah berikan kepadanya.Ia hanya perlu menerimanya dengan lapang dada dan yakin bahwa segala sesuatu yang menyulitkan pasti akan indah pada waktunya.

\section{d. Jujur}

Jujur merupakan sikap yang tidak dapat berbohong dan dapat dipercaya.Jujur merupakan salah satu sikap yang sangat disukai oleh Allah, karena Allah sangat membenci orang-orang yang suka berdusta.Dalam novel Bidadari Paderi tampak nilai kejujuran dalam beberapa tokoh sebagai berikut.

Kalau Jauhar mau jujur, secara diam-diam, dia memang sudah menaruh simpati pada Nilam yang kini sedang menjadi kembang nagari yang diincar para kumbang.(BP, 26).

Perasaan jatuh cinta yang dialami manusia merupakan sifat alamiah yang ada pada diri seseorang.Rasa cinta dan simpati yang timbul sebagai pembuktian bahwa seseorang telah dewasa.Hal itulah yang dirasakan oleh Jauhar pada kutipan di atas dalam novel Bidadari Paderi.Jauhar yang telah lama tertarik pada Nilamyang merupakan kembang desa, masih malu dan bimbang dalam mengungkapkan perasaannya. Rasa yang dialaminya membuat ia jujur terhadap dirinya sendiri, bahwa memang ia sudah sejak lama jatuh cinta pada Nilam, namun takut untuk mengakui hal tersebut karena status keluarga mereka yang berbeda. Nilam yang berasal dari keluarga yang berkecukupan, sedangkanJauhar hanyalah seorang anak yatim piatu yang tidak memiliki apa-apa untuk dibanggakan.

Kutipan tersebut terdapat alur sorot balik yang ditampilkan melalui konteks yang dibangun oleh pengarang untuk memberikan kejutan kepada pembaca tentang kisah percintaan Jauhar.Konteks kutipan di atas, yaitu saat Jauhar mengingat kembali pertemuan dengan Nilam di surau yang membuat hatinya berdebar.Rasa berdebar yang ditunjukkan oleh Jauhar secara langsung menyiratkan rasa jatuh cinta yang dialami semua orang. Pada kenyataannya seorang laki-laki cenderung akan mengatakan perasaan dan isi hatinya jika menyangkut dengan wanita yang ia sukai. Hal itu pula 
sesuai dengan kodrat seorang lelaki yang mencari dan menyatakan bukan dicari dan menunggu.

\section{e. Ikhlas}

„Ikhlas" menurut Kamus Besar Bahasa Indonesia adalah bersih hati dan tulus hati (ed.3. Pusat Bahasa. 2005). Artinya seseorang tidak menyesal dalam melakukan sesuatu. Orang yang ikhlas dalam melakukan suatu pekerjaan dengan niat yang baik tidak akan mengharapkan balasan apapun kepadanya selain balasan dari Allah.Ikhlas merupakan sikap yang sangat terpuji yang han ya dapat dilakukan oleh orang-orang yang bertakwa kepada-Nya, karena mengikhlaskan sesuatu bukan hanya dari niat yang tulus tetapi juga atas dasar wujud keimanannya kepada Allah.Sehingga jika diberi cobaan yang berat ia mampu melewati cobaan tersebut dan mengikhlaskan yang telah terjadi, seperti yang digambarkan pengarang melalui tokoh Jauhar dalam novel Bidadari Paderi. Banyak cobaan yang menimpa dirinya tetapi ia tetap bersabar dan ikhlas menerima semua itu.

\section{"Kalau soal Hasan, kami semua sudah ikhlas.Kami bisa menerima kepergiannya yang mulia seperti itu.Meninggal ketika hendak shalat subuh di surau." (BP, 378).}

Keikhlasan seseorang dalam menerima cobaan merupakan sikap religiusitas kepada Allah, apalagi menyangkut kerelaan terhadap orang yang disayangi.Keikhlasan tersebut ditunjukkan Jauhar melalui kutipan di atas yang menjelaskan mengenai kerelaan hati Jauhar menerima kepergian anaknya. Hasan yang merupakan putra sulungnya meninggal karena akan pergi sholat subuh mengikuti Jauhar. Ia yakin bahwa kepergian Hasan tidak akan sia-sia karena ia meninggal dalam keadaan yang suci dan mulia untuk menjalankan perintah Allah, karena jika seseorang ikhlas dalam melakukan suatu perbuatan kebajikan maka Allah akan memberi pahala untuknya, seperti yang dijelaskan dalam Al-Qur'ean (surah Al-Baqarah; 112). Sikap ikhlas yang digambarkan pengarang melalui tokoh Jauhar membuktikan bahwa mengikhlaskan sesuatu jika dengan niat yang tulus karena Allah, segala masalah dan cobaan yang datang akan mampu kita terima dengan hati yang lapang.

\section{f. Disiplin}

Menurut Kamus Besar Bahasa Indonesia „disipline adalah ketaatan atau kepatuhan seseorang terhadap waktu dan peraturan yang dibuat (ed.3. Pusat Bahasa. 2005). Seseorang yang disiplin tidakakan melanggar atau sampai lalai dalam melaksanakan peraturan tersebut.Orang yang displin pasti bertanggung jawab terhadap kewajibannya.Hal tersebut tergambar pada kutipan berikut ini.

“Mengajar anak-anak itu kan tanggung jawab kita sebagai guru di sini."(Bp, $53)$. 
Berdasarkan kutipan tersebut secara langsung pengarang telah menunjukkan sikap disiplin dalam cerita melalui tokoh Jauhar. Konteks kutipan di atas, yaitu saat Salim bertanya kepada Jauhar perihalketidakhadirannya untuk ikut latihan, tetapi ia tetap datang ke surau untuk mengajar mengaji.Hal tersebut membuat sahabatnya Salim bertanya-tanya. Jauhar yang tidak pernah ikut latihan bukan karena ia bermalasmalasan, tetapi ia memiliki tugas lain yang hanya diketahui oleh Imam Mudo saja.

Sikap Jauhar tersebut sangat mengindikasikan bahwa ia adalah seseorang yang sangat disiplin dan bertanggung jawab terhadap kewajibannya. Walaupun ia jarang datang ke surau untuk mengikuti latihan bela diri, tetapi ketika waktu untuk mengajar anak-anak mengaji, ia tetap datang ke surau untuk menjalankan kewajibannya sebagai seorang guru. Tidak mengikuti latihan bukan berarti juga tidak mengajar mengaji untuk anak-anak, ia tetap disiplin untuk menjalankan kewajibanya sebagai seorang guru mengaji.

\section{KESIMPULAN}

Berdasarkan hasil penelitian yang telah dilakukan terhadap novel Bidadari Paderi karya Saiful A. Imam dengan menggunakan kajian sastra religius yang berfokus pada nilai-nilai religiusitas, peneliti menemukan dua aspek nilai yang terkandung dalam novel tersebut, yaitu nilai keimanan (tauhid) dan nilai sikap perilaku (akhlak). Nilai keimanan (tauhid) terdiri dari; 1) iman, 2) takwa, 3) tobat.Sedangkan nilai sikap perilaku (akhlak) terdiri dari; 1) sabar, 2) rendah hati, 3) tawakal, 4) ikhlas, 5) jujur, dan 6) disiplin.

dari hasil analisis yang dilakukan terhadap dua aspek tersebut terdapat kriteria yang lebih dominan, yaitu nilai sikap perilaku. Hal ini terlihat pada data yang dikumpulkan, cenderung lebih banyak nilai sikap perilaku yang ditampilkan pengarang.Serta sesuai dengan kisah dalam novel yang menceritakan tentang perjuangan kaum paderi yang ingin melakukan pembaharuan ajaran Islam di Minangkabau.Pada saat itu masyarakat Minang masih teguh memegang kebiasaan dan adat-istiadat yang sangat bertentangan dengan ajaran-ajaran agama walaupun mereka telah memeluk agama Islam.Serta perjuangan kaum paderi dan kaum adat untuk melawan Belanda yang ingin menguasai daerah Minangkabau.

Dominasi nilai sikap perilaku dalam novel Bidadari Paderi memberikan makna bahwa sebagai makhluk yang memiliki agama tidak cukup hanya dengankeyakinan terhadap Tuhan saja. Namun, keyakinan tersebut harus dibuktikan dengan akhlak yang mencerminkan keimanan kepada Sang Pencipta sehingga orang tersebut akan benarbenar dikatakan religius. Jadi dapat disimpulkan bahwa nilai keimanan dan nilai sikap perilaku merupakan dua sisi yang saling berkaitan. Sama halnya dengan yang dikatakan oleh Mangunwijaya (1998: 13-14) yang dikutip dari sebuah Al-Kitab yang mengatakan bahwa, "seperti tubuh tanpa roh adalah mati, demikian jugalah Iman tanpa perbuatanperbuatan adalah mati”. 
Nilai-Nilai Religiusitas dalam Novel Bidadari Paderi Karya Saiful A. Imam.

\section{DAFTAR PUSTAKA}

Imam, A. Saiful. 2007.Bidadari Paderi. Jakarta:Republika.

Jauhari, Heri. 2010. Cara Memahami Nilai Religius dalam Karya Sastra.Bandung: Arfino Raya.

Moleong, J. Lexy. 2017. Metodologi Penelitian Kualitatif. Bandung:Remaja Rosdakarya.

Mangunwijaya, Y.B. 1992. Sastra dan Religiositas. Yogyakarta: Kanisius.

Pusat Bahasa. 2005. Kamus Besar Bahasa Indonesia, Edisi ke-3. Jakarta: Balai Pustaka 